\title{
VOLATILE COMPOUNDS OF Nectandra salicina (LAURACEAE) FROM COSTA RICA AND THEIR CYTOTOXIC ACTIVITY ON CELL LINES
}

\author{
José F. Cicció* and Carlos Chaverri \\ Centro de Investigaciones en Productos Naturales and Escuela de Química, Universidad de Costa Rica, 2060 San José, \\ Costa Rica \\ Cecilia Díaz \\ Instituto Clodomiro Picado, Facultad de Microbiología and Departamento de Bioquímica, Escuela de Medicina, Universidad de \\ Costa Rica, 2060 San José, Costa Rica
}

Recebido em 1/8/08; aceito em 8/9/08; publicado na web em 5/2/09

\begin{abstract}
The chemical composition of the volatiles of Nectandra salicina growing wild in Costa Rica was determined by capillary GC/FID and GC/MS. Thirty-seven and forty-two compounds were identified in the leaf and branch oils respectively corresponding to about 92.6 and $86.2 \%$ of the total amount of the oils. The major components of the leaf oil were: atractylone (14.6\%), viridiflorene (10.1\%), $\alpha$-pinene (9.4\%), $\beta$-caryophyllene (7.2\%), $\alpha$-humulene (7.0\%), $\delta$-cadinene (6.1\%), $\beta$-pinene $(6.0 \%)$ and germacrene $\mathrm{D}(5.8 \%)$. The major components of the branch oil were: atractylone $(21.1 \%)$, germacrene D (10.7\%), viridiflorene (7.9\%) and 7-epi- $\alpha$-selinene (5.0\%). When the oils were tested on different cell lines, all the $\mathrm{LD}_{50}$ values were higher than $150 \mu \mathrm{g} / \mathrm{mL}$, with values very similar for the leaf and branch oils. Low toxicity could be explained by antagonistic effects among the main compounds present in the oils.
\end{abstract}

Keywords: Nectandra salicina; volatiles; cytotoxicity.

\section{INTRODUCTION}

Nectandra is a New World genus constituted by approximately 100 to 150 species, ranging from Florida to Argentina, with the majority of species present in South America. ${ }^{1}$ In Costa Rica, this genus is represented by about 20 species. It belongs to the Lauraceae family, which is present with abundance and diversity of species in the Cloud Forests of Costa Rica, together with plants of the Leguminosae (Fabaceae) family. ${ }^{2}$ The majority of the species produce relatively small fruits which are of great ecological importance for the sustenance of several mammals such as monkeys and kinkajous, and birds such as quetzals and toucans., ${ }^{2,3}$ The Lauraceae family is recognized by the simple, alternate, stiff and aromatic elliptic to obovate leaves, and by the fruits often borne in a cup. Worldwide, this family has a considerable economic value because it is used as a source of timber for construction and furniture, as food (Persea americana Mill., Avocado), to obtain flavors for food industry, drinks and perfumery and medicines [Cinnamomum camphora (L.) J. Presl., Camphor Laurel].

Nectandra salicina C. K. Allen is a tree (5-10 m tall) from evergreen forests, which is found in both the Caribbean and Pacific slopes of Costa Rica, from about 600 to $1,700 \mathrm{~m}$ of elevation. It is commonly known as ira, canelo and aguacatillo ${ }^{4}$ and is recognized by its small lustrous narrowly elliptic and acuminated leaves, with the tertiary veins, usually prominent on both surfaces. Inflorescences are small, few-flowered with pink red rachises and puberulent little flowers. Fruits are ellipsoid to globose and borne in shallow cups. ${ }^{1}$

Many members of the Nectandra genus have been chemically investigated and they are mainly characterized by the occurrence of alkaloids,${ }^{5-10}$ lignans,,${ }^{11-13}$ neolignans,,${ }^{14-17}$ tetrahydrofuranoid lignans, ${ }^{18}$ norlignans, ${ }^{19}$ dehydrodieugenols ${ }^{20}$ and $\gamma$-lactones. ${ }^{21,22}$

The composition of several essential oils from $N$. angustifolia (syn. N. falcifolia) ${ }^{23-25} N$. coriacea ${ }^{26} N$. elaiophora ${ }^{27}$ and $N$. rigida ${ }^{28}$

*e-mail: jfciccio@gmail.com has been published. However, to the best of our knowledge, only one previous report on the composition of the leaf oil from $N$. salicina appears in the scientific literature. ${ }^{29}$

\section{EXPERIMENTAL}

\section{Plant material}

Leaves and branches of Nectandra salicina C. K. Allen, Lauraceae, growing wild in Costa Rica were collected in June 2001, in Fraijanes, Miramar, Province of Puntarenas, Costa Rica. A voucher specimen was deposited at the Herbarium of the University of Costa Rica (USJ 76991).

\section{Oil isolation}

Fresh leaves $(1.0 \mathrm{~kg})$ and chipped fresh branches $(1.5 \mathrm{~kg})$ were subjected to hydrodistillation for $3 \mathrm{~h}$ using a modified Clevengertype apparatus. The distilled light yellow oils were collected and dried over anhydrous sodium sulfate and stored in a freezer (0-10 $\left.{ }^{\circ} \mathrm{C}\right)$. Leaf and branch essential oil yields were $0.1 \%$ (v/w) and $0.2 \%$ $(\mathrm{v} / \mathrm{w})$, respectively.

\section{General analytical procedures}

\section{GC/FID analysis}

The oils of $N$. salicina were analyzed by GC/FID using a Shimadzu GC-17 gas chromatograph. The data were obtained on a 5\% phenyl- 95\% methylpolysiloxane fused silica capillary column (30 m x $0.25 \mathrm{~mm}$; film thickness $0.25 \mu \mathrm{m}$ ), Heliflex (Alltech) AT-5, with a Shimadzu Class-VP, version 4.3 software. Operating conditions were: carrier gas $\mathrm{N}_{2}$, flow $1.0 \mathrm{~mL} / \mathrm{min}$; oven temperature program: $60-220$ ${ }^{\circ} \mathrm{C}$ at $3{ }^{\circ} \mathrm{C} / \mathrm{min}, 220{ }^{\circ} \mathrm{C}(10 \mathrm{~min})$; sample injection port temperature $250{ }^{\circ} \mathrm{C}$; detector temperature $275^{\circ} \mathrm{C}$; split 1:50. 


\section{GC/MS analysis}

The analyse by GC/MS were performed using a Shimadzu GC-17A gas chromatograph coupled with GCMS-QP5050 apparatus and CLASS 5000 software with Wiley 139 and NIST computer databases. The data were obtained on a 5\% phenyl- 95\% methylpolysiloxane fused silica capillary column ( $30 \mathrm{~m}$ x $0.25 \mathrm{~mm}$; film thickness $0.25 \mu \mathrm{m})$. Operating conditions were: carrier gas $\mathrm{He}$, flow $1.0 \mathrm{~mL} / \mathrm{min}$; oven temperature program: $60-220^{\circ} \mathrm{C}$ at $3{ }^{\circ} \mathrm{C} / \mathrm{min}$; sample injection port temperature $250{ }^{\circ} \mathrm{C}$; detector temperature $260^{\circ} \mathrm{C}$; ionization voltage: $70 \mathrm{eV}$; ionization current $60 \mu \mathrm{A}$; scanning speed $0.5 \mathrm{~s}$ over 38-400 amu range; split 1:70.

\section{Identification}

Identification of the oils components was performed using the arithmetic retention indices (RI) on DB-5 type column, ${ }^{30}$ and by comparison of their mass spectra with those published in the literature ${ }^{31}$ or those of our own database. Integration of the total chromatogram, expressed as area percent, has been used to obtain quantitative compositional data.

\section{Cell culture}

Mouse macrophage J774, human hepatoma HepG2, human leukemic K562 and mouse myoblastic C2C12 cell lines were obtained from American Type Culture Collection (ATCC). Cells were maintained in Dulbecco essential medium supplemented with $10 \%$ fetal bovine serum, $2 \mathrm{mmol} / \mathrm{L}$ of glutamine, $100 \mathrm{IU} / \mathrm{mL}$ of penicillin and amphotericin $\mathrm{B}$ in a $37^{\circ} \mathrm{C}$ humidified incubator under an atmosphere of $7 \% \mathrm{CO}_{2}$ in air. For the experiments, adherent cells were cultured in 96-well plates to confluence ( 15,000 cells/well) and allowed to adhere overnight. Non-adherent cells were also plated at 15,000/well.

\section{Cytotoxicity assay}

Various concentrations of essential oils, previously dissolved in $95 \%$ ethanol, were added to the plates in $100 \mu \mathrm{L}$ of fresh medium and incubated for $48 \mathrm{~h}$. After that, $10 \mu \mathrm{L}$ of [3-(4,5-dimethylthiazol2-yl)-2,5-diphenyltetrazolium bromide] (MTT) $(0.5 \mathrm{mg} / \mathrm{mL})$ was added to the culture and, after $2 \mathrm{~h}$ at $37{ }^{\circ} \mathrm{C}$, medium was carefully removed and $95 \%$ ethanol was added to the wells with the purpose of dissolving formazan crystals. Absorbances were read at $570 \mathrm{~nm}$ and results were expressed as viability percentages, using samples incubated with $95 \%$ ethanol dissolved in culture medium as $100 \%$ viability values. $\mathrm{LD}_{50}$ values were calculated with SlideWrite ${ }^{\circledR}$ Plus 6.1 (Advanced Graphics Software, Inc., Carlsbad, CA).

\section{RESULTS AND DISCUSSION}

N. salicina leaf and branch oil constituents are listed in Table 1. As it can be observed, 37 components were identified from the leaf, representing $92.6 \%$ of the essential oil. Monoterpene hydrocarbons $(17.4 \%)$, sesquiterpene hydrocarbons $(51.1 \%)$ and oxygenated sesquiterpenes $(22.4 \%)$ were the main constituents of the oil, and contained the monoterpenes $\alpha$-pinene $(9.4 \%), \beta$-pinene $(6.0 \%)$; the sesquiterpenes viridiflorene $(10.1 \%), \beta$-caryophyllene $(7.2 \%), \alpha$-humulene $(7.0 \%), \delta$-cadinene $(6.1 \%)$ and germacrene D $(5.8 \%)$, and the oxygenated sesquiterpene atractylone $(14.6 \%)$, as a main constituents. From the branch, 42 compounds were identified, representing $86.2 \%$ of the oil. This oil is constituted mainly of sesquiterpene hydrocarbons $(40.7 \%)$ and oxygenated sesquiterpenes (36.2\%). The major components of the branch oil were atractylone $(21.1 \%)$, germacrene D $(10.7 \%)$, viridiflorene $(7.9 \%)$ and 7 -epi- $\alpha$-selinene $(5.0 \%)$.

N. salicina from Costa Rica produced oils which are terpenoid in
Table 1. Percentage composition of the leaf and branch volatiles of Nectandra salicina

\begin{tabular}{|c|c|c|c|c|}
\hline Compound $^{\mathrm{a}}$ & $\mathrm{RI}^{\mathrm{b}}$ & Leaf & Branch & $\begin{array}{c}\text { Identification } \\
\text { Method }^{\mathrm{d}}\end{array}$ \\
\hline (3Z)-hexenol & 850 & 0.4 & & 1,2 \\
\hline (2E)-hexenol & 854 & 1.2 & & 1,2 \\
\hline$\alpha$-pinene & 932 & 9.4 & 3.2 & $1,2,3$ \\
\hline camphene & 944 & 0.8 & 1.2 & 1,2 \\
\hline$\beta$-pinene & 974 & 6.0 & 1.1 & $1,2,3$ \\
\hline myrcene & 987 & 0.4 & 0.2 & 1,2 \\
\hline$\alpha$-phellandrene & 1005 & 0.3 & 0.9 & 1,2 \\
\hline$\delta$-3-carene & 1006 & & 0.3 & 1,2 \\
\hline$\rho$-cymene & 1020 & 0.1 & 0.3 & 1,2 \\
\hline limonene & 1025 & 0.5 & 0.5 & $1,2,3$ \\
\hline bornyl acetate & 1284 & & 0.7 & 1,2 \\
\hline iso-dihydrocarveol acetate & 1324 & & 0.9 & 1,2 \\
\hline$\alpha$-cubebene & 1345 & & 1.0 & 1,2 \\
\hline$\alpha$-ylangene & 1372 & & $\mathrm{t}$ & 1,2 \\
\hline$\alpha$-copaene & 1374 & 1.7 & 1.4 & 1,2 \\
\hline$\beta$-elemene & 1388 & 1.0 & 0.7 & 1,2 \\
\hline$\beta$-longipinene & 1405 & 1.2 & & 1,2 \\
\hline$\beta$-caryophyllene & 1416 & 7.2 & 2.7 & $1,2,3$ \\
\hline$\beta$-gurjunene & 1433 & 0.8 & & 1,2 \\
\hline$\gamma$-elemene & 1434 & & 0.4 & 1,2 \\
\hline$\alpha$-humulene & 1449 & 7.0 & 2.5 & 1,2 \\
\hline dehydroaromadendrene & 1462 & 0.3 & 0.3 & 1,2 \\
\hline drima-7,9(4)-diene & 1469 & $\mathfrak{t}^{\mathrm{c}}$ & 0.4 & 1,2 \\
\hline$\alpha$-amorphene & 1481 & 4.5 & & 1,2 \\
\hline germacrene D & 1485 & 5.8 & 10.7 & 1,2 \\
\hline$\beta$-selinene & 1490 & & 4.6 & 1,2 \\
\hline viridiflorene & 1497 & 10.1 & 7.9 & 1,2 \\
\hline$\alpha$-muurolene & 1502 & 0.5 & 0.4 & 1,2 \\
\hline$\alpha$-bulnesene & 1509 & $\mathrm{t}$ & 0.1 & 1,2 \\
\hline$\gamma$-cadinene & 1512 & 2.9 & & $1,2,3$ \\
\hline 7-epi- $\alpha$-selinene & 1518 & 1.3 & 5.0 & 1,2 \\
\hline$\delta$-cadinene & 1523 & 6.1 & 2.3 & 1,2 \\
\hline zonarene & 1530 & 0.2 & 0.2 & 1,2 \\
\hline (Z)-nerolidol & 1533 & & 0.4 & 1,2 \\
\hline$\alpha$-cadinene & 1535 & 0.5 & 0.1 & 1,2 \\
\hline elemol & 1547 & & 0.8 & 1,2 \\
\hline spathulenol & 1575 & 1.1 & 2.3 & 1,2 \\
\hline $\begin{array}{l}\text { trans-sesquisabinene } \\
\text { hydrate }\end{array}$ & 1579 & 0.9 & & 1,2 \\
\hline himachalene epoxide & 1581 & & 1.2 & 1,2 \\
\hline guaiol g g & 1595 & & 0.6 & 1,2 \\
\hline humulene epoxide II & 1606 & 0.3 & 0.7 & 1,2 \\
\hline helifolen-12-al D & 1617 & & 1.1 & 1,2 \\
\hline
\end{tabular}


Table 1. continuing

\begin{tabular}{|c|c|c|c|c|}
\hline Compound $^{\mathrm{a}}$ & $\mathrm{RI}^{\mathrm{b}}$ & Leaf & Branch & $\begin{array}{l}\text { Identification } \\
\text { Method }^{\mathrm{d}}\end{array}$ \\
\hline 1,10-di-epi-cubenol & 1617 & 0.2 & & 1,2 \\
\hline 1-epi-cubenol & 1625 & 0.3 & 0.8 & 1,2 \\
\hline$\gamma$-eudesmol & 1632 & & $\mathrm{t}$ & 1,2 \\
\hline$\tau$-cadinol & 1637 & 3.2 & 0.6 & 1,2 \\
\hline$\tau$-muurolol & 1640 & & 1.7 & 1,2 \\
\hline atractylone & 1657 & 14.6 & 21.1 & 1,2 \\
\hline (Z)- $\alpha$-santalol & 1676 & 0.2 & 0.7 & 1,2 \\
\hline elemol acetate & 1679 & 0.2 & & $1,2,3$ \\
\hline isobicyclogermacrenal & 1729 & 1.4 & 4.2 & 1,2 \\
\hline Monoterpene hydrocarbons & & 17.5 & 7.7 & \\
\hline Oxigenated monoterpenes & & & 1.6 & \\
\hline $\begin{array}{l}\text { Sesquiterpene hydrocar- } \\
\text { bons }\end{array}$ & & 51.1 & 40.7 & \\
\hline Oxigenated sesquiterpenes & & 22.4 & 36.2 & \\
\hline Others & & 1.6 & & \\
\hline
\end{tabular}

${ }^{\mathrm{a} C}$ Compounds listed in order of elution from 5\% phenyl- 95\% methylpolysiloxane column. ${ }^{b} \mathrm{RI}=$ Arithmetic retention index (experimental) on 5\% phenyl- 95\% methylpolysiloxane column on reference to n-alkanes. $\mathrm{t}=$ Traces $(<0.05 \%)$. ${ }^{\mathrm{d}}$ Method: $1=$ Arithmetic retention indices on $5 \%$ phenyl- $95 \%$ methylpolysiloxane column; $2=\mathrm{MS}$ spectra; 3 = standard.

nature, as well as the oil from leaves of $N$. rigida from Brazil, which contains $\alpha$ - and $\beta$-phellandrenes $(72.8 \%)^{28}$ and the oil from the leaf of $N$. angustifolia from Argentina, which contains $p$-menth-1(7),8-diene $(25.2 \%)$ and terpinolene $(20.9 \%)$, as main constituents. ${ }^{25}$ The major component of both leaf and branch oils of $N$. salicina from Costa Rica was the oxygenated sesquiterpene atractylone (14.6 and $21.1 \%$ respectively). In the leaf oil, lesser amounts of the monoterpenes $\alpha$-pinene (9.4\%) and $\beta$-pinene (6.0\%); and the sesquiterpenes: viridiflorene (10.1\%), $\beta$-caryophyllene (7.2\%), $\alpha$-humulene $(7.0 \%), \delta$-cadinene $(6.1 \%)$ and germacrene D $(5.8 \%)$ are also present. In the branch oil, together with atractylone, we also found sesquiterpenes germacrene $\mathrm{D}(10.7 \%)$, viridiflorene $(7.9 \%)$ and 7 -epi- $\alpha$-selinene $(5.0 \%)$.

A previous report on the leaf volatile composition of $N$. salicina ${ }^{29}$ (from the Species Collection at South Coast Research and Experiment Station, UC, Riverside, USA), had indicated that the main constituents were indene $(30.1 \%)$ and the furanocoumarin methoxsalen $(24.5 \%)$. In our study, which characterizes the leaf oil of the plants growing in Costa Rica, the composition differs both qualitative and quantitatively from that previous report. We were unable to find any evidence of the presence of indene or methoxsalen in the leaf or branch volatiles of this wild tree. On the other hand, these results could be identifying a different chemotype of $N$. salicina, rich in atractylone, or could be reflecting edaphic and climate factors (ecotypes), since plants were not grown in the same environments.

When both volatiles were tested on four different cell lines: leukemic and hepatoma cells and two non-tumor cells (macrophages and myoblasts), low toxicity was observed. There was a little variation in the $\mathrm{LD}_{50}$ values on tumor cells, which were around $175 \mu \mathrm{g} / \mathrm{mL}$ for the branch oil whereas for the leaf oil, values were over $230 \mu \mathrm{g} / \mathrm{mL}$ (Figure 1). Both volatiles gave almost identical $\mathrm{LD}_{50}$ values on nontumor cells C2C12 and J774 (from 125 to $200 \mu \mathrm{g} / \mathrm{mL}$ ) (Figure 2).

Almost no cytotoxic effect was previously observed at the concen-
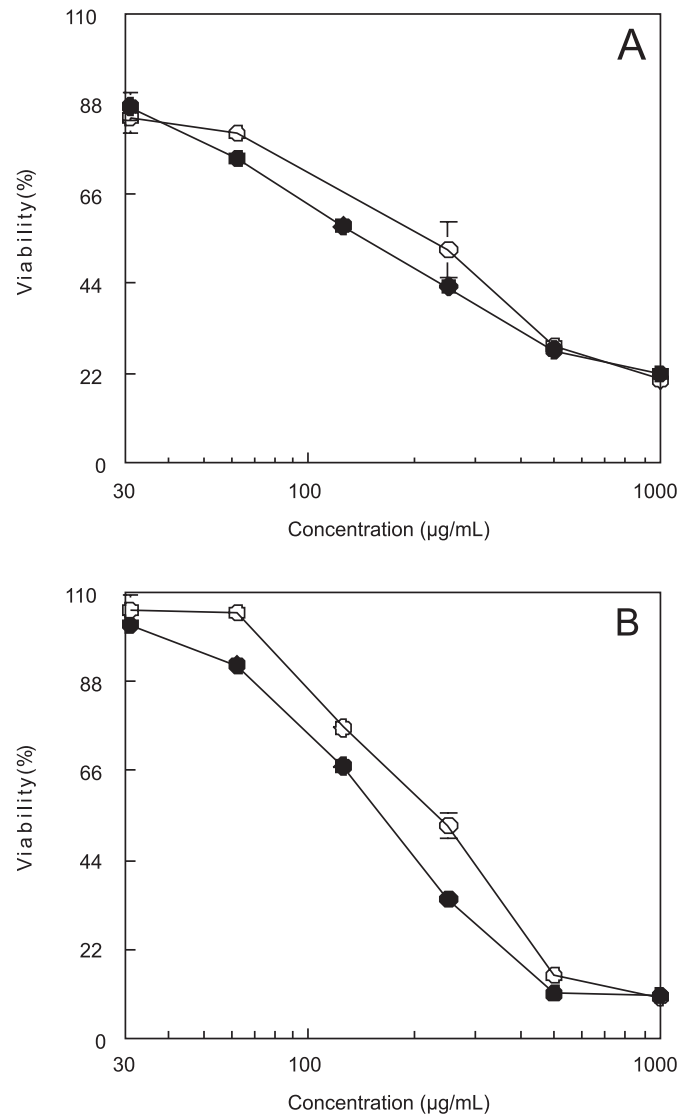

Figure 1. Cytotoxic activity of N. salicina oils on tumor cell lines. A. Leukemic cell line K562. B. Hepatocarcinoma cell line HepG2. Cells were treated for 48 $h$ with different oil concentrations dissolved in ethanol. $\bullet$ Leaf oil; $\circ$ branch oil. Results are presented as mean $\pm S E$ of one representative experiment performed in triplicate

tration of $100 \mu \mathrm{g} / \mathrm{mL}$ with Nectandra membranacea on the hepatoma cell line HepG $2,{ }^{32}$ the same cell line tested in our study. Some studies showed that leaf oils from Ocotea veraguensis, O. whitei and Persea americana, other members of the Lauraceae family, have no cytotoxic effect on mammary ductal carcinoma (MDA-MB-435) and ovarian adenocarcinoma (OVCAR-5), but they show toxicity at concentrations of $100 \mu \mathrm{g} / \mathrm{mL}$ in other mammary adenocarcinoma (MCF7, MDAMB-468, MDA-MB-231) and malignant melanoma UACC-257. ${ }^{33}$

In an interesting study, Wright et al. ${ }^{34}$ previously showed that essential oil components such as $\beta$-caryophyllene and $\alpha$-humulene present antagonistic effects when combined with $\alpha$-pinene. Since these are some of the main compounds present in $N$. salicina volatiles, it could partially explain the low cytotoxic activities observed in this study.

Also, even though it has been shown that atractylone has antiproliferative activity on leukemia cell lines (HL-60 and P-388) and normal peripheral blood mononuclear cells and is able to trigger apoptosis, ${ }^{35}$ its presence seems insufficient to induce high toxicity on the cells tested here. However, different atractylone concentrations present in $N$. salicina leaf and branch volatiles could partially explain differences in $\mathrm{LD}_{50}$ values observed between both samples.

This is the first report in the literature that shows the composition and cytotoxic characterization of the essential oils obtained from leaves and branches of $N$. salicina. It seems clear that, as other members of the Lauraceae family, these oils have low toxicity, possibly due to antagonistic effects induced by their main compounds, since some of these compounds ( $\alpha$ - and $\beta$-pinene, $\beta$-caryophyllene, $\alpha$-humulene), when tested individually, are able to induce high toxicity on tumor cells. ${ }^{34}$ 

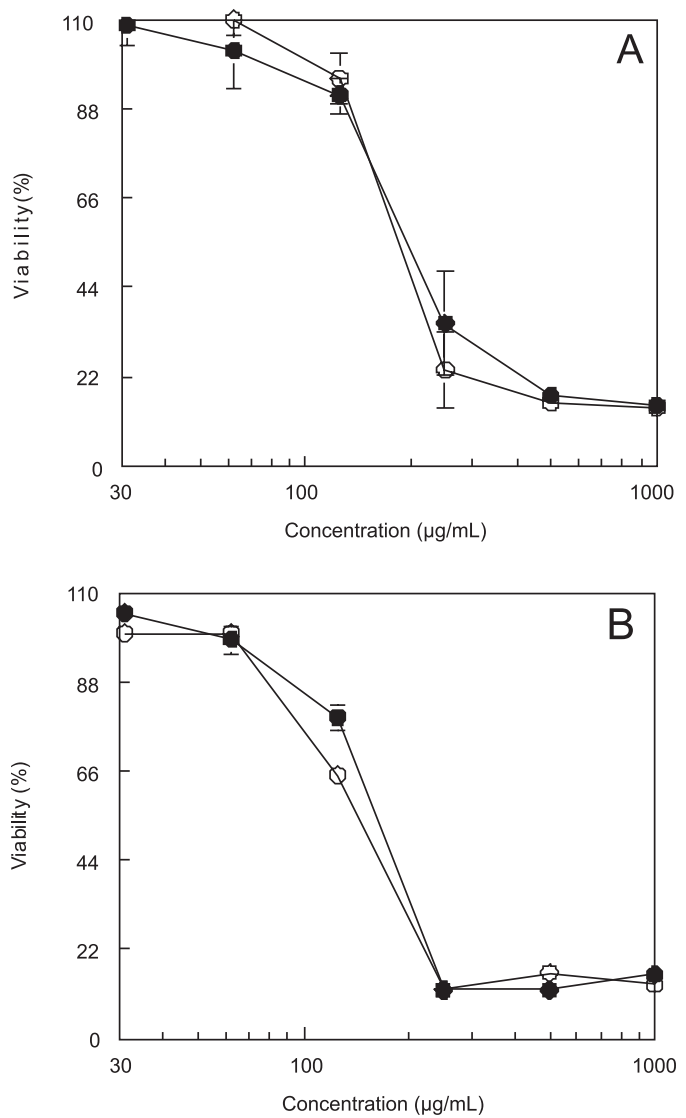

Figure 2. Cytotoxic activity of $N$. salicina oils on non-tumor cell lines. A. Macrophage cell line J774. B. Myoblastic cell line C2C12. Cells were treated for $48 \mathrm{~h}$ with different oil concentrations dissolved in ethanol. $\bullet$ Leaf oil; $\circ$ branch oil. Results are presented as mean \pm SE of one representative experiment performed in triplicate

\section{ACKNOWLEDGEMENTS}

The authors are grateful to Vicerrectoría de Investigación (UCR) (Project 809-A4-006) for financial support, to L. J. Poveda (Escuela de Ciencias Ambientales, Universidad Nacional) for the botanical identification and to L. Hernandez (CIPRONA) for her technical assistance. Partial funding was also obtained from FEES through Project No. 809-A8-518.

\section{REFERENCES}

1. Burger, W. C.; van der Werff, H.; Fieldina, Bot, n.s. 1990, 23, 1.

2. Haber, W. A.; Zuchowski, W.; Bello, E.; An introduction to Cloud Forest trees: Monteverde, Costa Rica, La Nación: San José, 1996, p. 130, 134.

3. Stiles, F.G. In Historia Natural de Costa Rica; Janzen, D. H., ed.; Editorial de la Universidad de Costa Rica: San José, 1991, Ch.10, p. 614.

4. León, J.; Poveda, L. J. In Los Nombres Comunes de las Plantas en Costa Rica; Sánchez-Vindas, P. E., ed.; Editorial Guayacán: San José, 2000, p. 586.

5. Castro-Castillo, O.; Rodriguez, G.; Poveda, L.; Fitoterapia 1989, 60, 474.

6. Castro-Castillo, O.; Hasbún-Pacheco, C.; Calderón, M.; Fitoterapia 1991, $62,72$.
7. Hasbún-Pacheco, C., Calderón, M.; Castro-Castillo, O.; Ing. Cienc. Quím. 1991, 13, 19.

8. Moreno, P. R. H.; von Poser, G. L.; Rates, S. M. K.; Yoshida, M.; Gottlieb, O. R.; Souza, I. A.; Henriques, A. T.; Int. J. Pharmacogn. 1993, $31,189$.

9. López, J. A.; Barillas, W.; Gómez-Laurito, J.; Lin, F.-T.; Al-Rehaily, A. J.; Sharaf, M. H. M.; Schiff Jr., P. L.; Planta Med. 1995, 61, 589.

10. Bohlke, M.; Guinaudeau, H.; Angerhofer, C. K.; Wongpanich, V.; Soejarto, D. D.; Farnsworth, N. R.; Mora, G. A.; Poveda, L. J.; J. Nat. Prod. 1996, 59, 576.

11. Barbosa-Filho, J. M.; Yoshida, M.; Gottlieb, O. R.; Phytochemistry 1989, 28, 1991.

12. De Carvalho, M. G.; Yoshida, M.; Gottlieb, O. R.; Gottlieb, H. E.; Phytochemistry 1986, 26, 265.

13. Da Silva Filho, A. A.; Albuquerque, S.; Silva, M. L. A. E.; Eberlin, M. N.; Tomazela, D. M.; Bastos, J. K.; J. Nat. Prod. 2004, 67, 42.

14. Aiba, C. J.; Gottlieb, O. R.; Pagliosa, F. M.; Yoshida, M.; Magalhães, M. T.; Phytochemistry 1977, 16, 745.

15. Braz Filho, R.; Figliuolo, R.; Gottlieb, O. R.; Phytochemistry 1980, 19, 659.

16. Moro, J. C.; Fernandes, J. B.; Vieira, P. C.; Yoshida, M.; Gottlieb, O. R.; Gottlieb, H. E.; Phytochemistry 1986, 26, 269.

17. Ribeiro, A. B.; Bolzani, V. S.; Yoshida, M.; Santos, L. S.; Eberlin, M. N.; Silva, D. H. S.; J. Braz. Chem. Soc. 2005, 16, 526.

18. Le Quesne, P. W.; Larrahondo, J. F.; Raffauf, R. F.; J. Nat. Prod. 1980, $43,353$.

19. Cherigo, L.; Polanco, V.; Ortega-Barria, E.; Heller, M. V.; Capson, T. L.; Rios, L. C.; Nat. Prod. Res. 2005, 19, 373.

20. Suarez, M.; Bonilla, J.; De Diaz, A. M. P.; Achenbach, H.; Phytochemistry 1983, 22, 609.

21. Franca, N. C.; Gottlieb, O. R.; Coxon, D. T.; Phytochemistry 1977, 16, 257.

22. Garcez, F. R.; Garcez, W. S.; Martins, M.; Cruz, A. C.; Planta Med. 1999, 65, 775 .

23. Fester, G. A.; Martinuzzi, E. A.; Retamar, J. A.; Ricciardi, A. I. A.; Rev. Fac. Ing. Quím. 1960, 29, 21.

24. Talenti, E. C. J.; Mancini, P. M. E.; Retamar, J. A.; Essenze, Deriv. Agrum. 1981, 51, 121.

25. Torres, A. M.; Ricciardi, G. A. L.; Agrelo de Nassif, A. E.; Ricciardi, A. I. A.; Dellacassa, E.; Comunicaciones Científicas y Tecnológicas. Universidad Nacional del Nordeste, Argentina, 2005, Resumen E-013, http://www.unne.edu.ar/Web/cyt/com2005/index.htm, accessed on June 2008.

26. Marbot, R.; Pino, J. A.; Paya, A.; Chao, D.; Herrera, D.; J. Essent. Oil Res. 2005, 17, 648.

27. Naves, Y. R.; Bull. Soc. Chim. Fr. 1951, 987.

28. Morais, A. A. de; Mourão, J. C.; Gottlieb, O. R.; Koketsu, M.; Moura, L. L.; da Silva, M. L.; Marx, M.C.; Mendes, P. H.; Magalhaes, M. T.; An. Acad. Bras. Ciênc. 1972, 44(Suppl.), 320.

29. Scora R. W.; Scora, P. E.; J. Essent. Oil Res. 2001, 13, 37.

30. van den Dool, H.; Kratz, P. D.; J. Chromatogr. 1963, 11, 463.

31. Adams, R. P.; Identification of Essential Oil Components by Gas Chromatography/ Quadrupole Mass Spectroscopy, $4^{\text {th }}$ ed., Allured: Carol Stream, 2007.

32. Werka J. S., Boehme A. K.; Setzer, W. N.; Nat. Prod. Commun. 2007, 2 , 1215.

33. Moriarity, D. M.; Bansal, A.; Cole, R. A.; Takaku, S.; Haber, W. A.; Setzer, W. N.; Nat. Prod. Commun. 2007, 2, 1263.

34. Wright, B. S.; Bansal, A.; Moriarity, D. M.; Takaku, S.; Setzer, W. N.; Nat. Prod. Commun. 2007, 2, 1241.

35. Wang, C.-C.; Chen, L.-G.; Yang, L.-L.; Planta Med. 2002, 68, 204. 